\title{
Modern University Teaching Meaningful Reconstruction: Combining Teaching with Research
}

\author{
ZHAO Tao ${ }^{1} \&$ ZHU Ye ${ }^{2}$ \\ ${ }^{1}$ Faculty of Education, Southwest University, Chongqing, China \\ Correspondence: ZHAO Tao, Faculty of Education, Southwest University, Chongqing, China. Tel: \\ 1-888-325-7525. E-mail: 517805746@QQ.com. ZHU Ye, Faculty of Education, Southwest University, \\ Chongqing, China. Tel: 1-830-609-9811. E-mail: 841924774@QQ.com
}

$\begin{aligned} & \text { Received: November 24, } 2014 \\ & \text { Accepted: December 10, } 2014 \quad \text { Online Published: December 30, } 2014 \\ & \text { doi:10.5539/ass.v11n3p366 }\end{aligned} \quad$ URL: http://dx.doi.org/10.5539/ass.v11n3p366

\begin{abstract}
For universities, teaching is the prerequisite and basis of research, and it promotes the increasing improvement of scientific research level; the scientific research is a source and power of teaching, research promotes the deepening of teaching content. The effectively integration of teaching and research gives a new meaning to the modern university teaching. The modern university teaching should be a process that absorbing creative achievements and making students have an access to the real knowledge, and that is the right teaching. The role of modern universities teacher is not only to preach, teach and disabuse, but also as a teacher and a researcher. It is said that "the best investigator should be the best catechist, the best catechist should be the best researcher", and it makes a new identity for college teachers. Under the background of combing teaching and research, the article tries to interpret the new meaning of the university teaching and the teachers' new responsibility.
\end{abstract}

Keywords: teaching, research, teaching and research, teaching meaning

\section{Introduction}

In university, teaching as the main activity to spread truth and profound knowledge, which should always adhere to the highest principle of the truth, and this principle will get useful supplement with the research entered. The exact relationship between teaching and research began in Berlin university which founded by Humboldt in the 19th century. Initially, the idea of combining between teaching and research got the sound function of the university which worked in the lecture- teaching mode. It was a major feature in teaching with research joined, and it was also a measure to improve the quality of teaching, promote student's creative thinking ability and practical capacity. Effectively combination of "teaching and research" made the development of higher education quickly at one time, which made scientific research became an important function of university. But In the mid-19th century, Newman thought that the unique function of a university is teaching universal knowledge to students and strongly opposed to the principle of combining of teaching and research. But the tide of history could not be stopped, with the rapid development of social sciences, "teaching and research" as a basic function of university had been gradually accepted by public all over the world. By the early 1900s, Van Hise proposed the social service as a function of university in the Wisconsin university. After that, "Wisconsin Idea" was diffused in many countries. Until now, teaching, research and community service have become widely recognized as three basic functions of higher education institutions.

\section{The Ideal and Reality of Combining Teaching and Research}

"A combination of teaching and research", began in the early 19th century, was an innovative concept of German universities. When Humboldt designed the principle of the new college, he said the university teaching must be combined with scientific research, the teachers should get innovative scientific research into their own teaching activities to promote their teaching, only like this way, and their teaching was the real meaning teaching in universities. Thus, the specific impress on teacher's professional life of Berlin University was: the excellent scholars not only had outstanding achievements in scientific research, but also had the most outstanding in teaching. According to German's concept, a university professor was a teacher, who also was a scientific investigator; but people paid more attention to the latter one, so we would say like this: in Germany, as a scientific researcher, who also taught college students in class." However, today, the "perfectly combination of teaching and research to promote the teaching "is an ideal for Humboldt, but the idea was not as he had imagined. 
In reality, the relationship between teaching and research was far from simple and linear, as the famous American scholar Burton Clark said, "Although research had already got into the university and established a link with teaching in a certain period, but to some extent, there still existed the teaching including no scientific research that called" teaching drift "and there still existed the scientific research including no teaching that called "research drift". So he said, "research and teaching were far from a natural match, they were able to organize within a single framework only under a special condition." The separation of teaching and research leads to the teacher's role confusion. It was a value selection that emphasis on research but contempt teaching made university teacher as a researcher prominent increasingly, but as a teaching role marginalize increasingly. Since the modern universities establishment, science research and social service has already became an important and indispensable duty for the university. Thus, university teacher not only had the responsibility to teaching, but also had the responsibility to do scientific research and social service works. "University teachers have already got into a place that full of professional challenges including knowledge production, technical assistance, community development and many other areas." However, this phenomenon had already existed in universities not only in our country but also all over the world. Yan Caihong was a teacher, who got full marks in students evaluating teaching activities in Shanghai Jiao Tong University, but he had not been commented on the associate professor until he death, because the number of his published papers was not enough (Note 1). Zhu senhua, who was loved by students in the department of Philosophy, Zhejiang University in China, owing to lack of the published papers, he could not be employed (Note 2). But only 25 -year-old Zhang hongwei, who was teaching in Guangxi University of China, because of outstanding research, he was named professor (Note 3). These events made this problem more prominent and led to a large number of teachers began to appear a strange phenomenon in China: teachers were not busy with teaching. Professors, especially a well-known professor, who teaching students have already became a luxury. The teacher, who wanted to become a good teacher, was no longer due to his contribution in teaching, but decided on his research and the number of published papers. And so on, these events made the problem about " emphasis on research but contempt teaching" had become more and more prominent and intolerable, which required us must understand the relationship between teaching and research. Therefore, we call for that "teachers should back to their own work in the condition of the effective combination between teaching and research, which will give a new mean to teaching.

\section{The Conditions of the Effective Combination between "Teaching and Research"}

The value of university teacher's teaching service is compared to that of scientific research, the former one is difficult to outstanding in a short time. It takes three generations to make a gentleman. The value of teaching service is a long-term and prospective. Instead, the university teachers' research achievements can bring direct benefits to themselves and university. These research achievements were published to the public. The level of teachers' research always be evaluated by some experts. Only in this way, the teachers' professional prestige will be built up gradually and the academic level of a faculty or academic units will be recognized by their peers" (Derek Bok, 2008, p. 20). Thus, it is the tendency for university management to regard the university teacher's scientific research as the main criteria that select and evaluate the teacher's ability. "Publish or perish" had became a university teacher's professional survival rules (Gong, 2011, p. 1). Therefore, if we want to achieve "the effective combination of teaching and research" in a university, we should satisfy the following conditions need.

\subsection{The Types of Universities Classification Is a Premise of the Effective Combination of Teaching and Research}

The combination of teaching and scientific research is not complete equality, but according to the type of school assignment. In recent years, the education authorities distinguish the university into research-universities, research-teaching-university, teaching-research-universities and teaching universities according to the type of university (Wu, 2002, p. 11). These different types schools have different requirements in the teaching, scientific research and social services. We can not regard the teaching and research as a whole nonadjustable contradiction, the contradiction between teaching and research is mainly reflected in the distribution of the time, but they are mutual promotion and complementary in content and nature. Research-university is different from the regular colleges. Its core mission is undergraduate education. Undergraduate education is a necessary but not sufficient condition to achieve the mission of research universities. Research universities not only aim at training undergraduate in basic professional knowledge, but also integrate their knowledge and creative ability, which needs to apply the thought of scientific research, process and methods into undergraduate teaching. The core mission of the research-universities which develop the undergraduate education is combine the teaching with the research; teaching-research or research-teaching universities are mainly in undergraduate education and develop graduate education moderately, these kinds of universities must base on a high level quality teaching and then carry out the scientific research activities. It also should according to their professional characteristics and 
advantages to allocate their teaching and research. They should be good at find their own superiority and highlight their own advantages and features, reflect the lifeblood of disciplines in order to play the advantages of their belongings. The undergraduate teaching is the core of the teaching-oriented colleges or universities, which regards the training applied talents as a fundamental task, takes specialized technical innovation and development as the core, takes the local economic construction and social development as the mainly target. These kinds of colleges offer applied talents for development of local social-economic. Therefore, the establishment of a diverse system of higher education provide the preconditions for the effective combination of teaching and research.

\subsection{Establishing the Diverse Evaluation Criteria for the Universities Is a Necessary Condition of Combining Teaching and Research}

Currently, there exist one major issue that the criteria for evaluation is too single in the process of assess all colleges and universities. Especially it's only taking the assessing research-universities as a criteria to evaluate all universities. This assessment as a role of identification and guiding, it's naturally causing a series of subsequent reactions that the university pays attention to what the school administration concern about and then make a choice. Therefore, many universities under the guidance of a higher assessment criteria, regardless of their training objectives and tasks to blind compare with each other and even regardless of the their self- limiting condition to emphasis on " research first". As a result, the number of scientific research superficial prosperity but the quality was not high. At the same time, the level of teaching was going down. The university administration, under in the process of the diversification of higher education system, should take diversified assessment criteria to ensure the quality of all colleges and universities. It's also should depend on the type of university to divide the different quality standards and use the different criteria to evaluate the quality of various types of colleges and universities (Derek Bok, 2008, p. 20). Thus, it's avoiding the current situation that many universities emphasis on research but contempt teaching. What's more, it also avoids the different tape of universities to blind comparison. Only like this way, it can make different types of colleges and universities to play their own advantages, which is a necessary condition for combining teaching with research.

\subsection{It Is an Effective Guarantee for the Combination of Teaching and Research to Improve the Management and the Evaluation of Higher Education}

From the perspective of management science, it promotes the effective combination of teaching and research is an important measure to strengthen the management of teaching and research. Now, it exists a widespread phenomenon that emphasis on research but contempt teaching in universities, It's over highly emphasis on the number of research achievements and forces teachers to do more research achievements (such as publish a number of papers, etc). Some teachers are lack of attention on their teaching work, and aim at get more time and energy to engage in their research work. They are unwilling to engage in the basic education, this phenomenon is more common in research-universities. As the former dean of Harvard College Professor Harry Lewis in his book "The lost soul of excellence: why forgotten education by a famous university" (Lewis, 2006) said that "today, many research-universities had already forgotten that teaching was their primary task, which was replaced by the academic and scientific research. This was called "the lost soul of excellence". These issues become obstacles to improve their teaching quality. Therefore, teaching and research should be taken strictly evaluation and rational management by the management agencies, no matter what types and levels of universities. To some extent, it will make this combination more valuable under in a high quality of teaching and research condition. Therefore, it's an effective guarantee for the combination of teaching and research to improve the management and evaluation of higher education

\section{4. "The Combination of Teaching and Research." Creates a New Meaning of Teaching}

From the perspective of the economics knowledge, the scientific research is subjective form of cultivate innovative talents, knowledge production, and knowledge application; it's also the main method for university, which is a think-tank or a knowledge base in society. Scientific research is a think-tank for colleges and universities.

Teaching and research are two aspects of a thing. In other words, teaching and research is a mission of the university teacher. Teaching and learning are two aspects of a process what university teachers need to complete. Teaching is a process, which contained sharing of knowledge, explore, and discover knowledge. The university is a place where knowledge-transfer, knowledge innovation, and cultural transmission. Academician Qian Weichang once said, "The wall must be dismantled between teaching and research in university. If there is no scientific research joins in the teaching, it will be a no view or no soul education." (Qian, 2003, pp. 16-20) Combination of university teaching and research in order to reflect their significance of teaching. University 
teachers should get their scientific research achievements into their teaching activities, which is the real meaning of the teaching. University teacher should become a lancer who majors in both teaching and research. The way of university teaching is not only a form of university research, and university research should not be separated from teaching. The best researcher should be the best teacher and the best teacher should be the best researcher. Why we can say that "the best researcher is the best teacher", because "only can the research lead the people to touch a real learning process and even realize the scientific spirit". That also because it will not have an outstanding teaching without research. It's hard to arouse the outstanding awareness and action.so it's also hard to cultivate outstanding talents. The aim of university education is cultivate talents who should possess the scientific research and the innovation ability. Scientific research is necessary for the teachers who carry out an effective teaching. Karl Theodor Jaspers, the world famous educator in Germany, who is one of the four sages once said, "the people who engaged in scientific research could teach their scientific research achievements to others." (Jaspers, 1991, p. 152)

Teaching is a way that the university teachers can express their research results or elaborate a point of view. So, to some extent, the teaching is not the full significance of teaching without research involved. However, it is not easy to find a balance between the teaching and research. This is not only the core issues in the university, but also the role orientation issues of university teachers.

\section{Conclusion}

Combining teaching and research is a part of university teacher's duty. University has its own special character when it compares with the general educational, it's mainly performance in the process of scientific exploration, both teachers and students are combined into a academic community, teachers guide students to carry out research activities to achieve " unity of teaching and research ". The sense of combining teaching and scientific research is embodied in the fact that scientific research activities are required to offer new ideas and inspiration to knowledge structure, with which teaching concerns and then offers directions for graduates and postgraduates with more extensive and more updated knowledge. Thus, in this sense, the combination of teaching and research is a part of the university teacher's responsibility. As Stanford University President John L. Hennessy in his book named "Teaching at Stanford" wrote that: "Stanford University promises that it would became an outstanding in their science research and teaching. We gave emphasis on teaching and the same as we gave emphasis on the scientific research work; we believed that this was not only possible but essential. As a teacher at Stanford, who was an academic staff or assistant, your knowledge in the relevant fields has been recognized, but we demand that you also have set an example in teaching work".

Combining teaching and research should highlight the basic duty of teaching, in order to promote the teaching much better. Only by getting actively involved into the scientific research activities can teachers meld knowledge gained and innovated through scientific innovative activities into teaching and course system. Encourage the teachers who are major in research get their research achievements apply into their teaching, and encourage the teachers who are major in teaching regard their part of teaching contents as the research achievements." In order to overcome the teachers who are major in research neglect the teaching and the teachers who are major in teaching ignore scientific research. It's better to promote this interaction between each other, it should get rid of those types which simply determine tasks and authorized strength and establish consecutive and reasonable conversion ratio. It has different task allocation for different types of teachers. But a combination of both is better to service for teaching. Over all, it's in the form of teaching that passed the knowledge down. As in Germany, University teachers participate in the scientific research activities and the basic motivation is to spread scientific knowledge. Addition, its purposes is to serve the teaching. Such as Germany's Bauer Health puts it, "In Germany, the direct purpose for people to create knowledge is oral teaching, and this is not the same place in another ". Therefore, teaching becomes the teacher's duty as a starting point and end point; it should be the basic duty for each teacher.

Jaspers regard the combination of teaching and research as the supreme fundamental principles, but he still puts forward a particular requirement for this combination: "university teachers are not only as research scholars, but also more sensitive to their commitment to teaching responsibilities and fulfill this responsibility in their own research activities, It's play an important part to the teaching significance of scientific research." (Jaspers, 1991, p. 153) Teachers should show the process of exploring scientific truth to students, guide students to explore the spirit of scientific research, which can play an important part to the value of the combination of teaching and research.

Combination of teaching and research is a realistic choice for higher education. It's also help teachers do better in teaching, University is the soul of education, university is the root of science and the university is the soul of 
culture. The root of the university teacher is that "teacher should settle down to read authentic and lean over to teaching". In other words, teaching is the university has become the root of the school; teacher has become the fundamental of the teacher. Research is better serve for the teaching, the ultimate goal of the combination is to more effective complete the core mission of universities, which called "talent cultivation". This is the life of the university. In this sense, "the combination of teaching and research" is just a means to give university teachers teaching effectively.

\section{Reference}

Derek Bok. (2008). It should return to the University of the Road: American undergraduate education reflection and prospect (p. 20). East China Normal University Press.

Gong, J., \& Zhang, J. (2011). Combining teaching and research is mission of undergraduate education (p. 1). Computer Education in China.

Wu, S. L. (2002). Revisited the classification of universities (p. 11). Science and Management of China.

Lewis, H. R. (2006). Excellence without a Soul: How a great university forgot education. New York:Public Affairs.

Qian, W. C. (2003). The wall of university teaching and research must be removed (pp. 16-20). Masses in China. Jaspers. (1991a). What is education (p. 152). Life study and cognitive bookstore in China.

Jaspers. (1991b). What is education (p. 153). Life study and cognitive bookstore in China.

\section{Notes}

Note 1. "Liberation Daily" published a report in china on March 16, 2005, it said that his teaching is very good, but until his death in his 57-year-old, because of lack of papers, he is still just a lecturer.

Note 2. "People's Daily" published about a teacher on November 24, 2005, whose name is Jewson in the Department of Philosophy, Zhejiang University. He is "laid off "by the University.

Note 3. "China Youth Daily" on February 23, 2005.An article about "a 25 -year-old person who was promoted to a professor, we can know the issue about "Emphasis on research but contempt teaching".

\section{Copyrights}

Copyright for this article is retained by the author(s), with first publication rights granted to the journal.

This is an open-access article distributed under the terms and conditions of the Creative Commons Attribution license (http://creativecommons.org/licenses/by/3.0/). 